\title{
Kajian Ketersediaan Air Baku Wilayah Perbatasan Aruk-Sajingan Besar Studi Kasus Desa Sebunga Kecamatan Sajingan Besar Kabupaten Sambas
}

\author{
Reza Wahyudi ${ }^{1}$, Wahyu Prayitno ${ }^{1}$, Muhammad Elifant Yuggotomo² \\ ${ }^{1}$ Program Studi Teknik Lingkungan, Universitas Nahdlatul Ulama Kalimantan Barat, Pontianak \\ ${ }^{2}$ BMKG Stasiun Klimatologi Mempawah, Kalimantan Barat \\ * Corresponding author: ${ }^{1}$ rezawahyudihse49@gmail.com
}

\begin{abstract}
One of the Indonesian government's policies to support border areas is the supply of raw water in border areas. This was carried out by an order to support the development and development program of the Aruk - Sajingan Besar border area, which was intended to accelerate development in the border area which has been known as a backward area. To support the development and development of the Aruk border region, various attempts have been made by the central government and the provincial government of West Kalimantan. This research is one of the efforts to support the government program by examining the availability of raw water in the Aruk-Sajingan Besar border area. Based on the results of the hydrological study at the study site, the mainstay discharge of raw water reaches $0.5-2 \mathrm{m3} / \mathrm{sec}$ with large evapotranspiration of 3-4 mm/day. Furthermore, this study also projects water needs for the next 25 years, these results are compared with the availability of raw water so that it can be concluded that up to 2045 the people of Sebunga Village, Sajingan Besar District, Sambas Regency, water needs can be met.
\end{abstract}

Keywords: border;raw water; hydrology; reliable discharge.

\begin{abstract}
ABSTRAK
Salah satu kebijakan pemerintahan Indonesia untuk mendukung daerah perbatasan yaitu penyediaan air baku di daerah perbatasan. Hal ini dilakukan oleh pemerintah guna mendukung program pengembangan dan pembangunan kawasan perbatasan Aruk - Sajingan Besar yang dimaksudkan untuk mempercepat pembangunan pada kawasan perbatasan yang selama ini dikenal sebagai kawasan tertinggal. Untuk mendukung pengembangan dan pembangunan kawasan perbatasan Aruk ini, berbagai upaya telah dilakukan oleh pemerintahan pusat serta pemerintahan provinsi Kalimantan Barat. Penelitian ini merupakan salah diantara upaya mendukung program pemerintah tersebut dengan mengkaji ketersediaan air baku di daerah perbatasan Aruk-Sajingan Besar. Berdasarkan hasil kajian hidrologi pada lokasi kajian bahwa debit andalan air baku mencapai 0,5 - $2 \mathrm{~m}^{3} /$ detik dengan besar evapotranspirasi 3-4 $\mathrm{mm} /$ hari. Selain itu, penelitian ini juga memproyeksikan kebutuhan air sampai dengan 25 tahun kedepan, hasil tersebut dibandingkan dengan ketersediaan air baku sehingga dapat disimpulkan bahwa sampai dengan tahun 2045 masyarakat Desa Sebunga Kecamatan Sajingan Besar Kabupaten Sambas kebutuhan air dapat dipenuhi.
\end{abstract}

Kata Kunci: perbatasan; air baku; hidrologi; debit andalan.

\section{PENDAHULUAN}

Kawasan perbatasan merupakan manifestasi utama kedaulatan wilayah suatu negara. Perbatasan suatu negara mempunyai peranan penting dalam penentuan batas wilayah kedaulatan, pemanfaatan sumber kekayaan alam, dan menjaga keamanan serta keutuhan wilayah. Perbatasan negara dalam banyak hal ditentukan oleh proses historis, politik, dan hukum nasional serta internasional (Moeldoko, 2014). Kawasan perbatasan juga memiliki nilai strategis dalam pembangunan nasional yaitu sebagai satu diantara faktor pendorong dari peningkatan perekonomian nasional secara umum serta meningkatkan nilai sosial dari masyarakat di sekitar kawasan perbatasan.

Berdasarkan kesepakatan yang dihasilkan dari pertemuan pemerintah Indonesia dan Malaysia mengenai kawasan perbatasan yang dilakukan di Medan, Sumatera Utara pada tanggal 12-13 April 2002, telah disepakati beberapa daerah yang menjadi pintu masuk (entry point) untuk masing-masing negara. Wilayah Provinsi Kalimantan Barat sendiri memiliki 16 entry points, dimana Temajuk, Liku, 
Sajingan Besar, dan Aruk termasuk di dalamnya. Kawasan perbatasan antar negara memiliki potensi strategis bagi berkembangnya kegiatan perdagangan internasional yang saling menguntungkan. Kawasan ini juga berpotensi besar menjadi pusat pertumbuhan wilayah, terutama dalam hal pengembangan industri, perdagangan dan pariwisata. Hal ini akan memberikan peluang bagi peningkatan kegiatan produksi yang selanjutnya akan menimbulkan berbagai efek pengganda (multiplier effects). (Mukti, Sri Handoyo. 2003)

Salah satu kebijakan pemerintahan Indonesia untuk mendukung daerah perbatasan yaitu penyediaan air baku di daerah perbatasan. Hal ini dilakukan oleh pemerintah guna mendukung program pengembangan dan pembangunan kawasan perbatasan Paloh - Sanjingan Besar yang dimaksudkan untuk mempercepat pembangunan pada kawasan perbatasan yang selama ini dikenal sebagai kawasan tertinggal. Untuk mendukung pengembangan dan pembangunan kawasan perbatasan Aruk ini, berbagai upaya telah dilakukan oleh pemerintahan pusat serta pemerintahan provinsi Kalimantan Barat. Berdasarkan latar belakang tersebut, guna mempersiapkan kebutuhan air baku diperlukan kajian mengenai kontinuitas ketersedian air baku di daerah perbatasan Aruk Sanjingan Besar dalam rangka mendukung pengembangan dan pembangunan kawasan perbatasan. Penelitian ini mengenai kualitas, kuantitas dan kontinuitas penyediaan air bersih di daerah perbatasan Aruk-Sanjingan Besar yang dilaksanakan di Desa Sebunga, Kecamatan Sanjingan Besar, Kabupaten Sambas.

\section{METODE PENELITIAN}

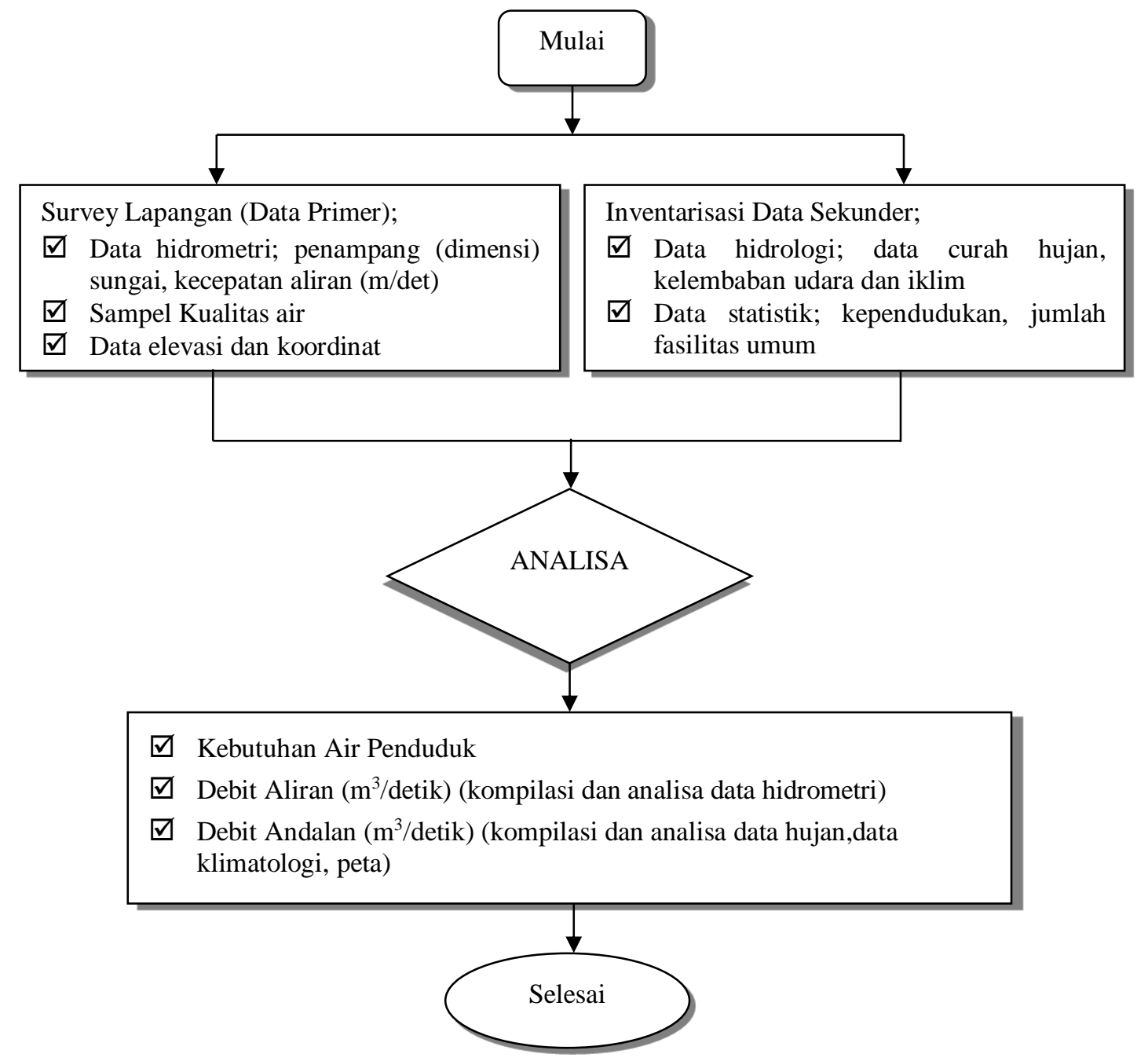

Gambar 1. Diagram Alir Penelitian 
Metodologi adalah pengetahuan tentang metode yang dipakai. Sedangkan metode adalah cara yang telah teratur dan terpikir baik-baik untuk mencapai suatu maksud (Purwadarminta, 2006). Jadi metodologi dapat diartikan sebagai suatu pengetahuan tentang cara yang telah teratur dan terpikir baikbaik untuk mencapai suatu maksud. Dalam suatu penelitian diperlukan suatu metodologi, agar hasil yang didapatkan sesuai dengan rancangan yang sistematis. Dalam penelitian ini, metode yang digunakan adalah deskriptif dan lapangan. Sehingga data yang digunakan terdiri atas data sekunder dan data primer. Tahap-tahap penelitian secara garis besar dapat dilihat pada Gambar 1.

Metode pengumpulan data pada penelitian ini adalah sebagai berikut:

2.1. Studi Literatur dan Inventarisasi Data Sekunder

Metode ini dilakukan untuk memperoleh data secara langsung dari instansi terkait yang berkaitan dengan penelitian ini. Data yang dicari dapat berupa laporan - laporan resmi yang di keluarkan oleh SKPD terkait.

\subsection{Survey dan Observasi}

Metode survey dan observasi dilakukan dengan melakukan survey secara langsung di lapangan untuk mengamati situasi wilayah penelitian dan melakukan pengukuran hidrometri serta pengambilan sampel kualitas air baku pada wilayah penelitian. Pengukuran hidrometri yang dimaksud yaitu mengukur penampang (dimensi) sungai dan kecepatan aliran ( $\mathrm{m} /$ detik).

a. Pengukuran Penampang Sungai

Pengumpulan data penampang sungai (data lebar aliran, kedalaman aliran kecepatan aliran) melalui pendekatan Velocity Area Method (Gordon et al., 1992) dengan maksud untuk mendapatkan luas penampang basah. Pengumpulan data penampang sungai dilakukan dengan mengukur lebar aliran dan kedalaman aliran. Pengukuran dilakukan dengan menggunakan meteran (lebar penampang) dan papan duga (kedalaman aliran $\leq 3 \mathrm{~m}$ ) atau alat pemberat (kedalaman aliran $\geq 3 \mathrm{~m}$ ). Dalam memilih penampang saluran biasanya digunakan penampang berbentuk persegi atau trapesium, tergantung data yang dimiliki.

$>$ Penampang Persegi Panjang (Gambar 2)

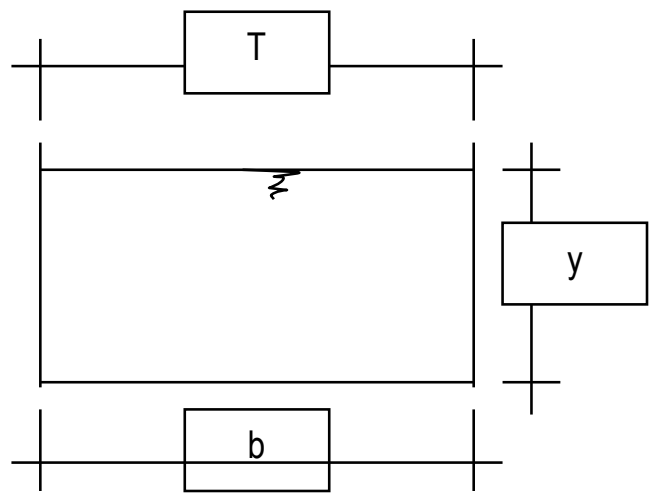

Gambar 2. Bentuk Penampang Persegi Panjang (Triadmojo, B. 1993b)

Penampang Trapesium (Gambar 3)

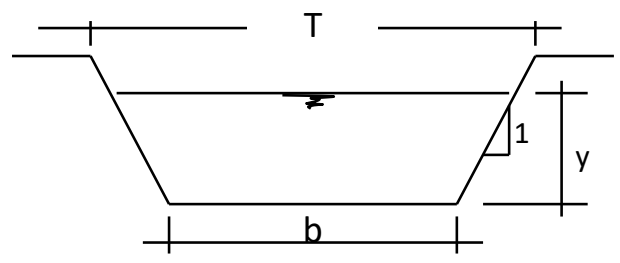

Gambar 3. Bentuk Penampang Trapesium (Triadmojo, B. 1993b) 
Namun terkadang kondisi di lapangan tidak memungkinkan kita untuk mengukur sedetaildetailnya. Sehingga untuk luas (A) penampang basah dapat didekati secara matematis dengan persamaan trapezium (Persamaan 1)

$$
A=\left(\frac{a+b}{2}\right) t \quad \text { (Persamaan 1) }
$$

Dengan a $=\mathrm{T}=$ lebar puncak, $\mathrm{b}=$ lebar dasar saluran, $\mathrm{t}=\mathrm{y}=$ kedalaman aliran, sehingga persamaan 1.1. dapat ditulis menjadi:

$$
A=\left(\frac{T+b}{2}\right) y
$$

(Persamaan 2)

Berdasarkan data lapangan yang didapat, maka dalam perhitungan debit pengukuran, bentuk penampang sungai didekatkan dengan bentuk trapesium, dengan persamaan luas penampang basah yang digunakan adalah persamaan 1.

\subsection{Wawancara}

Metode ini merupakan wawancara terbuka yang dilakukan dengan tujuan untuk mengetahui secara langsung kondisi eksisting ketersedian air bersih di wilayah penelitian. Wawancara dilakukan kepada perangkat desa guna mengetahui permasalahan air bersih yang terjadi di Desa Sebunga serta potensi sumber air baku yang diberada di lokasi penelitian.

\subsection{Metode Pengukuran Kecepatan Aliran Sungai}

Pengumpulan data kecepatan aliran rata-rata didapat dengan cara mengukur kecepatan aliran pada beberapa titik dari beberapa vertikal pada suatu penampang melintang dengan menggunakan alat ukur arus current meter (SNI 03-2819, 1992). Kecepatan aliran disetiap titik dihitung berdasarkan jumlah putaran baling-baling selama periode waktu tertentu. Pengukuran debit lapangan dilakukan dengan membagi penampang sungai menjadi 3 (tiga) pias, yakni pada Penampang 1, Penampang 2 dan Penampang 3. Masing-masing pias dilakukan pengukuran kecepatan aliran dan apabila kedalaman air antara 0,25 sampai 0,76 meter (Soewarno, 2000), dapat digunakan metode satu titik dimana hasil pengukuran pada titik 0,6 kedalaman aliran ini adalah merupakan kecepatan rata-rata pada vertikal yang bersangkutan.

Pengukuran debit lapangan dapat dilakukan pada kedalaman 0,2, 06, dan 0,8 kedalaman aliran saat pengukuran pulang dan pengukuran pergi, cara ini berlaku apabila kedalaman air yang diukur tidak kurang dari 0,76 meter. Dalam cara ini kecepatan rata-rata tiap vertikal diperoleh dengan merata-ratakan hasil pengukuran pada 0,2 dan 0,8 kedalaman aliran kemudian hasil rata-ratanya dirata-ratakan lagi dengan hasil pengukuran pada kedalaman aliran.Hasil pengukuran debit lapangan ini nantinya akan dibandingkan dengan hasil perhitungan debit andalan. Untuk penelitian ini, pengumpulan data kecepatan aliran rata-rata didapat dengan cara mengukur kecepatan aliran pada beberapa titik dari beberapa vertikal pada suatu penampang melintang dengan menggunakan alat ukur arus current meter valeport model 002, dengan alat ini kecepatan aliran dapat langsung diperoleh selama periode waktu tertentu.

Kondisi di Indonesia periode waktu berkisar antara 40-70 detik (Soewarno, 2000). Jumlah vertikal ditentukan berdasarkan pertimbangan keadaan sebaran aliran, bentuk profil (dangkal, dalam atau tidak teratur), waktu yang tersedia. Pada umumnya setiap negara mempunyai aturan yang berbedabeda dalam penentuan jumlah vertikal. Untuk Indonesia umumnya minimal 20 vertikal. Pengukuran yang dilakukan meliputi pengukuran pergi dan pengukuran pulang. Namun penentuan jumlah pias ini akan dilakukan berdasarkan kondisi lapangan. Untuk menghitung debit pengukuran dilakukan dengan mengkompilasi data penampang sungai dan data kecepatan aliran rata-rata. Kecepatan aliran (v) diukur pada kedalaman 0,$2 ; 0,6 ; 0,8$ (kecuali untuk beberapa titik yang tidak memungkinkan dilakukan pengukuran 0,$2 ; 0,6 ; 0,8$ kedalaman, pengukurannya hanya dilakukan pada 0,6 kedalaman). Untuk pengukuran 0,$2 ; 0,6 ; 0,8$ kedalaman (tiga titik), nilai $\bar{v}$ dicari dengan Persamaan 3.

$$
\bar{v}=\frac{1}{2} \times\left[0.6+\left(\frac{v_{0.2}+v_{0.8}}{2}\right)\right]
$$

(Persamaan 3) 
Untuk pengukuran yang hanya dilakukan pada 0.6 kedalaman, $\overline{\mathrm{v}}=\mathrm{v}_{0.60}$. Dalam penelitian ini, pengukuran dilakukan pada 3 pias, yakni pada $1 / 4 \mathrm{~L}, 1 / 2 \mathrm{~L}$ dan $3 / 4 \mathrm{~L}$ pada kedalaman $0.2,0.6$ dan $0.8 \mathrm{~h}$.

\subsection{Metode Analisa Debit Andalan}

Analisa Debit Andalan yaitu perhitungan aliran sungai dari data hujan, evapotranspirasi dan karakteristik hidrologi daerah pengaliran untuk menaksir tersedianya air di sungai (Mock, F.J. 1973)

\subsection{Metode Analisa Sampel Kualitas Air}

Sampel kualitas air mengacu pada PP R.I. No. 82 Tahun 2001 Tentang Pengelolaan Kualitas Air dan Pengendalian Pencemaran.

\section{HASIL PEMBAHASAN}

Analisis kuantitas air dalam penelitian ini dengan mengalihragamkan data curah hujan menjadi debit aliran. Hal ini dikarenakan tidak tersedianya data debit terukur dengan record panjang pada sumber air baku yang akan didesain. Pengalihragaman dilakukan dengan menggunakan Metode Mock. Dalam menggunakan metode Mock, diperlukan data hujan dan hari hujan, luasan catchment area dan besarnya evapotranspirasi potensial. Dalam penelitian ini, besarnya evapotranspirasi potensial diperkirakan dengan menggunakan metode Penman modifikasi (Suhardjono, 1994).

Berdasarkan tabel 1, hasil analisis evopotranspirasi dapat dilihat bahwa nilai rata-rata tahunan yang didapat adalah berkisar antara 3-4 $\mathrm{mm} / \mathrm{hari}$. Dari nilai rata-rata terlihat bahwa terjadi penurunan pada bulan November - Januari tetapi yang tinggi pada tidak terlalu besar perbedaan nilainya hal ini kemungkinan dikarenakan sudah jenuhnya air akibat intensitas hujan yang sangat tinggi pada bulan tersebut. Dengan evapotranspirasi tertinggi adalah 4,82 mm/hari yang terjadi pada bulan Februari 2014. Dan nilai evapotranspirasi terendah adalah $2,67 \mathrm{~mm} / \mathrm{hari}$ yang terjadi pada bulan Januari tahun 2015 . Hasil analisis evapotranspirasi berdasarkan hasil perhitungan data yang didapat dari BMKG Klimatologi Siantan sesuai pada Tabel 1.

Tabel 1. Resume Hasil Analisis Evapotranspirasi Di Desa Sebunga

\begin{tabular}{ccccccccccccc}
\hline \multirow{2}{*}{ Tahun } & \multicolumn{1}{c}{ Jan } & Feb & Mar & Apr & Mei & Jun & Jul & Ags & Sep & Okt & Nop & Des \\
\hline 2014 & 3.46 & 4.82 & 3.94 & 4.56 & 3.89 & 4.05 & 4.30 & 3.60 & 3.85 & 3.26 & 2.99 & 3.02 \\
\hline 2015 & 2.67 & 3.42 & 4.26 & 4.48 & 4.19 & 2.98 & 4.01 & 4.06 & 4.05 & 3.67 & 3.13 & 3.35 \\
\hline 2016 & 3.38 & 2.97 & 3.91 & 4.03 & 3.36 & 2.88 & 3.49 & 4.64 & 4.15 & 3.51 & 3.05 & 2.94 \\
\hline 2017 & 3.27 & 3.68 & 4.12 & 3.88 & 3.67 & 3.05 & 3.13 & 3.83 & 3.83 & 3.26 & 3.53 & 2.87 \\
\hline 2018 & 2.81 & 3.89 & 4.44 & 3.90 & 3.69 & 2.96 & 3.95 & 4.63 & 3.58 & 3.12 & 3.31 & 3.62 \\
\hline SUM & 15.59 & 18.78 & 20.67 & 20.84 & 18.80 & 15.91 & 18.87 & 20.77 & 19.47 & 16.82 & 16.02 & 15.78 \\
\hline MAX & 3.46 & 4.82 & 4.44 & 4.56 & 4.19 & 4.05 & 4.30 & 4.64 & 4.15 & 3.67 & 3.53 & 3.62 \\
\hline MIN & 2.67 & 2.97 & 3.91 & 3.88 & 3.36 & 2.88 & 3.13 & 3.60 & 3.58 & 3.12 & 2.99 & 2.87 \\
\hline Rerata & 3.12 & 3.76 & 4.13 & 4.17 & 3.76 & 3.18 & 3.77 & 4.15 & 3.89 & 3.36 & 3.20 & 3.16 \\
\hline
\end{tabular}

(Sumber: Hasil Perhitungan, 2019)

Berdasarkan tabel 2, hasil analisis Debit menggunakan metode MOCK dapat dilihat bahwa nilai rata-rata tahunan yang didapat adalah berkisar antara $0,5-2 \mathrm{~m}^{3} / \mathrm{detik}$. Dari nilai rata-rata terlihat bahwa terjadi penurunan pada bulan Juli sampai September hal ini kemungkinan terjadi akibat dipengaruhi oleh musim kemarau. Dengan debit tertinggi adalah 2,91 $\mathrm{m}^{3} /$ detik yang terjadi pada bulan Desember 2017. Dan nilai debit terendah adalah $0,05 \mathrm{~m}^{3} /$ detik yang terjadi pada bulan Juli 2014 dan September tahun 2016.

Hasil analisis Debit sungai berdasarkan hasil perhitungan di lapangan dan data pendukung yang didapat dari BMKG Klimatologi Siantan sesuai pada Tabel 2. 
Tabel 2. Resume Hasil Analisis Debit Bulanan Di Desa Sebunga

\begin{tabular}{|c|c|c|c|c|c|c|c|c|c|c|c|c|}
\hline \multirow{2}{*}{ Tahun } & \multicolumn{12}{|c|}{ Bulan ( $\mathrm{m}^{3} /$ detik) } \\
\hline & Jan & Feb & Mar & Apr & Mei & Jun & Jul & Ags & Sep & Okt & Nov & Des \\
\hline 2014 & 1.25 & 0.61 & 0.90 & 0.28 & 0.20 & 0.13 & 0.05 & 0.78 & 0.59 & 1.22 & 2.20 & 2.57 \\
\hline 2015 & 2.59 & 2.51 & 0.69 & 0.68 & 0.19 & 1.08 & 0.31 & 0.51 & 0.29 & 0.40 & 1.40 & 1.26 \\
\hline 2016 & 1.37 & 1.76 & 1.87 & 1.20 & 1.45 & 0.75 & 0.31 & 0.15 & 0.05 & 1.59 & 2.57 & 2.70 \\
\hline 2017 & 1.71 & 1.63 & 0.58 & 1.06 & 0.92 & 1.26 & 1.53 & 0.91 & 0.80 & 1.46 & 1.03 & 2.91 \\
\hline 2018 & 2.45 & 1.45 & 0.53 & 0.90 & 0.77 & 1.37 & 0.51 & 0.15 & 0.85 & 1.63 & 1.57 & 1.16 \\
\hline SUM & 9.37 & 7.95 & 4.56 & 4.13 & 3.53 & 4.59 & 2.71 & 2.50 & 2.58 & 6.31 & 8.77 & 10.61 \\
\hline MAX & 2.59 & 2.51 & 1.87 & 1.20 & 1.45 & 1.37 & 1.53 & 0.91 & 0.85 & 1.63 & 2.57 & 2.91 \\
\hline MIN & 1.25 & 0.61 & 0.53 & 0.28 & 0.19 & 0.13 & 0.05 & 0.15 & 0.05 & 0.40 & 1.03 & 1.16 \\
\hline Rerata & 1.87 & 1.59 & 0.91 & 0.83 & 0.71 & 0.92 & 0.54 & 0.50 & 0.52 & 1.26 & 1.75 & 2.12 \\
\hline
\end{tabular}

(Sumber: Hasil Perhitungan, 2019)

Berdasarkan pada Tabel 3 dan Gambar 4, terlihat bahwa pada bulan Juni-September Desa Sebunga akan mengalami penyusutan. Hal ini dikarenakan pada bulan tersebut biasanya memasuki musim kemarau, dimana intensitas curah hujan berkurang. Setelah melakukan perhitungan dengan menggunakan data-data di atas, Debit andalan Desa Sebunga sesuai pada Tabel 3 dan Gambar 4.

Tabel 3. Debit Andalan 99\% Desa Sebunga

\begin{tabular}{lc}
\hline Bulan & Debit $\left(\mathbf{m}^{\mathbf{3}} / \mathbf{d e t i k}\right)$ \\
\hline Januari & 1.051 \\
\hline Februari & 0.271 \\
\hline Maret & 0.443 \\
\hline April & 0.236 \\
\hline Mei & 0.161 \\
\hline Juni & 0.106 \\
\hline Juli & 0.044 \\
\hline Agustus & 0.123 \\
\hline September & 0.046 \\
\hline Oktober & 0.340 \\
\hline November & 0.871 \\
\hline Desember & 0.979 \\
\hline Rata & $\mathbf{0 . 3 8 9}$ \\
\hline (Sumber: Hasil Perhitungan, 2019$)$
\end{tabular}

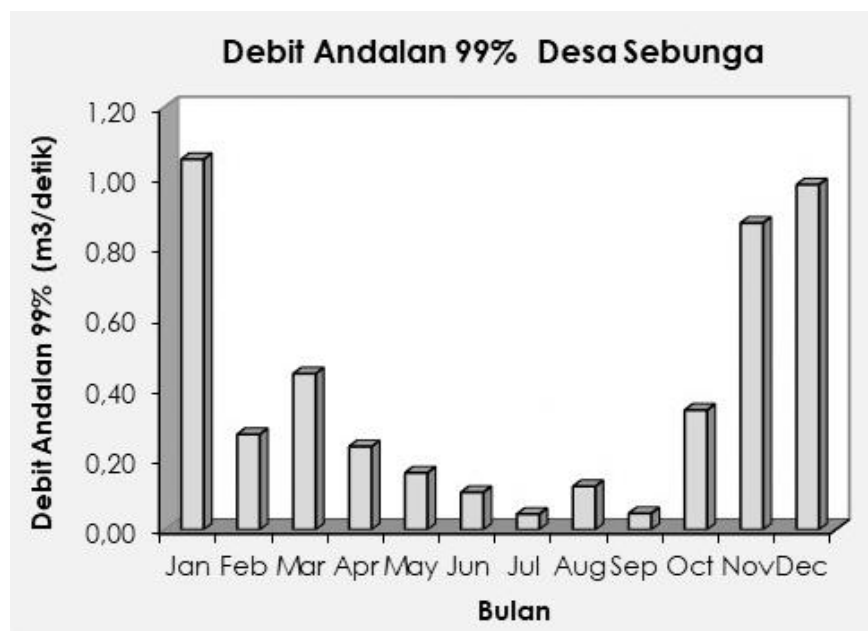

Gambar 4. Grafik Debit Andalan 99 \% Desa Sebunga

(Sumber: Hasil Perhitungan, 2019) 


\subsection{Analisa Kualitas Air}

Analisis terhadap sampel air diperlukan untuk mengetahui kualitas air sumber air baku yang akan digunakan. Hasil analisis kualitas air dapat menunjukkan apakah sumber air baku layak dijadikan sumber air bersih dan juga dapat dijadikan sebagai salah satu acuan untuk pengolahan air baku tersebut menjadi air bersih. Dalam penelitian ini, Analisis laboratorium dilakukan di laboratorium uji Dinas Kesehatan Provinsi Kalimantan Barat, dengan acuan batas maksimum adalah PP R.I. No. 82 Tahun 2001. Berdasarkan hasil uji laboratorium pada Tabel 4 dapat diketahui bahwa tidak ada parameter yang melebihi ambang batas minimal sehingga dapat dijadikan sumber air baku.

Tabel 4. Hasil Uji Laboratorium Kualitas Air di Desa Sebunga Dusun Aping

\begin{tabular}{|c|c|c|c|c|c|c|c|}
\hline \multirow{2}{*}{ No } & \multirow{2}{*}{ Parameter } & \multirow{2}{*}{ Satuan } & \multicolumn{4}{|c|}{ Kelas Mutu } & \multirow{2}{*}{ Hasil Uji } \\
\hline & & & I & II & III & IV & \\
\hline 1. & Residu Tersuspensi (TSS) & $\mathrm{mg} / \mathrm{L}$ & 50 & 50 & 400 & 400 & 3 \\
\hline 2. & Residu Terlarut (TDS) & $\mathrm{mg} / \mathrm{L}$ & 1000 & 1000 & 1000 & 2000 & 15 \\
\hline 3. & Temperatur & ${ }^{\circ} \mathrm{C}$ & deviasi 3 & deviasi 3 & deviasi 3 & deviasi 5 & 23,3 \\
\hline 4. & Arsen (AS) & $\mathrm{mg} / \mathrm{L}$ & 0,005 & 1 & 1 & 1 & 0,00 \\
\hline 5. & Amoniak $\left(\mathrm{NH}_{4}\right)$ & $\mathrm{mg} / \mathrm{L}$ & 0,5 & $(-)$ & $(-)$ & $(-)$ & 0,03 \\
\hline 6. & Besi (Fe) & $\mathrm{mg} / \mathrm{L}$ & 0,3 & $(-)$ & $(-)$ & $(-)$ & 0,02 \\
\hline 7. & $\mathrm{COD}^{\#)}$ & $\mathrm{mg} / \mathrm{L}$ & 10 & 25 & 50 & 100 & 5,0 \\
\hline 8. & BOD & $\mathrm{mg} / \mathrm{L}$ & 2 & 3 & 6 & 12 & 1,0 \\
\hline 9. & DO & $\mathrm{mg} / \mathrm{L}$ & 6 & 4 & 3 & 0 & 5,8 \\
\hline 10. & Fluorida (F) & $\mathrm{mg} / \mathrm{L}$ & 0,5 & 1,5 & 1,5 & $(-)$ & 0,37 \\
\hline 11. & Klorida $(\mathrm{Cl})$ & $\mathrm{mg} / \mathrm{L}$ & 1 & $(-)$ & $(-)$ & $(-)$ & 10 \\
\hline 12. & Klorin bebas, sebagai $\left(\mathrm{Cl}_{2}\right)$ & $\mathrm{mg} / \mathrm{L}$ & 0,03 & 0,03 & 0,03 & $(-)$ & 0,03 \\
\hline 13. & Kromium Valensi $6\left(\mathrm{Cr}^{6}\right)$ & $\mathrm{mg} / \mathrm{L}$ & 0,05 & 0,05 & 0,05 & 0,01 & 0,01 \\
\hline 14. & Mangan (Mn) & $\mathrm{mg} / \mathrm{L}$ & 1 & $(-)$ & $(-)$ & $(-)$ & 0,0 \\
\hline 15. & Nitrat $\left(\mathrm{NO}_{3}\right)$ & $\mathrm{mg} / \mathrm{L}$ & 10 & 10 & 20 & 20 & 0,00 \\
\hline 16. & Nitrit $\left(\mathrm{NO}_{2}\right)$ & $\mathrm{mg} / \mathrm{L}$ & 0,06 & 0,06 & 0,06 & $(-)$ & 0,00 \\
\hline 17. & $\mathrm{pH}^{\#)}$ & - & $6-9$ & $6-9$ & $6-9$ & $5-9$ & 6,73 \\
\hline 18. & Seng $(\mathrm{Zn})$ & $\mathrm{mg} / \mathrm{L}$ & 0,05 & 0,05 & 0,05 & 2 & 0,2 \\
\hline 19. & Sianida $(\mathrm{CN})$ & $\mathrm{mg} / \mathrm{L}$ & 0,02 & 0,02 & 0,02 & $(-)$ & 0,001 \\
\hline 20. & Sulfat $\left(\mathrm{SO}_{4}\right)$ & $\mathrm{mg} / \mathrm{L}$ & 400 & $(-)$ & $(-)$ & $(-)$ & 7,25 \\
\hline 21. & Sulfida $\left(\mathrm{H}_{2} \mathrm{~S}\right)$ & $\mathrm{mg} / \mathrm{L}$ & 0,002 & 0,002 & 0,002 & $(-)$ & 0,001 \\
\hline 22. & Tembaga (CU) & $\mathrm{mg} / \mathrm{L}$ & 0,02 & 0,02 & 0,02 & 0,2 & 0,007 \\
\hline 23. & Total Fosphat $\left(\mathrm{PO}_{4}\right)$ & $\mathrm{mg} / \mathrm{L}$ & 0,2 & 0,2 & 1 & 5 & 0,07 \\
\hline 24. & Fenol & $\mathrm{mg} / \mathrm{L}$ & 1 & 1 & 1 & $(-)$ & 0,25 \\
\hline 25. & Minyak \& Lemak & $\mathrm{mg} / \mathrm{L}$ & 1000 & 1000 & 1000 & $(-)$ & 0,45 \\
\hline 26. & Deterjen (MBAS) & $\mathrm{mg} / \mathrm{L}$ & 200 & 200 & 200 & $(-)$ & 0,75 \\
\hline
\end{tabular}

(Sumber: Hasil Uji Labotorium, 2019)

\subsection{Hasil Analisis Kebutuhan Air}

Kebutuhan air di Desa Sebunga berdasarkan proyeksi jumlah penduduk yang dapat dilihat pada Tabel 5, pada tahun 2020-2045 kebutuhan total pada tahun 2045 mencapai 7,82 liter/detik dan kebutuhan jam puncak pada tahun 2045 mencapai 14,41 liter/detik. Berdasarkan perhitungan debit andalan diketahui bahwa jumlah air yang dihasilkan oleh mata air di Desa Sebunga rata-rata mencapai 389 liter/detik dan berdasarkan pengukuran debit di lapangan didapatkan nilai 219 liter/detik. Sehingga berdasarkan hal tersebut kebutuhan air masyarakat di Desa Sebunga dapat terpenuhi hingga tahun 2045.

Kebutuhan air di Desa Sebunga berdasarkan proyeksi jumlah penduduk pada tahun 2020-2045 kebutuhan total pada tahun 2045 mencapai 7,82 liter/detik dan kebutuhan jam puncak pada tahun 2045 mencapai 14,41 liter/detik. Berdasarkan perhitungan debit andalan diketahui bahwa jumlah air yang dihasilkan oleh mata air di Desa Sebunga rata-rata mencapai 389 liter/detik dan berdasarkan pengukuran debit di lapangan didapatkan nilai 219 liter/detik. Sehingga berdasarkan hal tersebut kebutuhan air masyarakat di Desa Sebunga dapat terpenuhi hingga tahun 2045. 
Kontinuitas sumber air baku harus selalu dijaga walaupun catchment area nya merupakan daerah hutan lindung, terutama dari penebang-penebang liar yang dapat merusak ekosistem di hutan sehingga dapat mempengaruhi kualitas, kuantitas dan kontinuitas (K3) dari sumber tersebut.

Tabel 5. Kebutuhan Air Desa Sebunga

\begin{tabular}{lcccccc}
\multicolumn{1}{c}{ Uraian } & \multicolumn{7}{c}{ Tahun } \\
\cline { 2 - 7 } & $\mathbf{2 0 2 0}$ & $\mathbf{2 0 2 5}$ & $\mathbf{2 0 3 0}$ & $\mathbf{2 0 3 5}$ & $\mathbf{2 0 4 0}$ & $\mathbf{2 0 4 5}$ \\
\hline Kebutuhan Total (liter/detik) & 2.96 & 3.84 & 4.76 & 5.82 & 7.05 & 7.82 \\
\hline Kehilangan 20 \% (liter/detik) & 0.59 & 0.77 & 0.95 & 1.16 & 1.41 & 1.56 \\
\hline Total kebutuhan rata-rata (liter/detik) & 3.55 & 4.61 & 5.71 & 6.99 & 8.45 & 9.38 \\
\hline Total kebutuhan rata-rata (m $/$ detik) & 0.00 & 0.00 & 0.01 & 0.01 & 0.01 & 0.01 \\
\hline Kebutuhan harian puncak (liter/detik) & 4.26 & 5.53 & 6.85 & 8.38 & 10.15 & 11.25 \\
\hline Kebutuhan harian puncak (m ${ }^{3} /$ detik) & 0.00 & 0.01 & 0.01 & 0.01 & 0.01 & 0.01 \\
\hline Kebutuhan jam puncak (liter/detik) & 6.21 & 8.06 & 9.99 & 12.23 & 14.80 & 16.41 \\
\hline Kebutuhan jam puncak $\left(\mathrm{m}^{3} /\right.$ detik) & 0.01 & 0.01 & 0.01 & 0.01 & 0.01 & 0.02 \\
\hline
\end{tabular}

(Sumber: Hasil Perhitungan, 2019)

\section{KESIMPULAN}

Berdasarkan analisa hidrologi terkait dengan ketersedian air baku di Desa Sebunga guna mendukung daerah perbatasan Aruk - Sajingan Besar dengan membandingkan dengan analisa kebutuhan air di Desa Sebunga maka dapat disimpulkan bahwa ketersediaan air baku desa Sebunga dapat terpenuhi hingga tahun 2045.

\section{UCAPAN TERIMA KASIH}

1. Terimakasih kepada Lembaga Penelitian dan Pengabdian Masyarakat (LPPM) UNU Kalbar yang telah membantu dalam proses administari penelitian ini.

2. Terimakasih kepada Kantor Stasiun Klimatologi Mempawah yang telah membantu dalam menganalisa data yang digunakan dalam analisa pada penelitian ini.

\section{DAFTAR PUSTAKA}

Gordon, A.L., Weiss, R.F., Smethie, W.M. and Warner, M.J. (1992). Thermocline and intermediate water communication between the south Atlantic and Indian Ocean. Journal of Geophysical Reasearch 97: doi: 10.1029/92JC00485. Issn: 0148-0227.

Mock FJ. 1973. Land Capabilty Appraisal Indonesia, Water Availability Appraisal. UNDP-FAO. Bogor. Mukti, Sri Handoyo. 2003. "Konsep Pengembangan Kawasan Perbatasan Kalimantan Indo Malay Techno Agropolitan Corridor (IMTAC)”. Bulletin Tata Ruang, hal. 8-9. September-Oktober.

Moeldoko, 2014. "Kompleksitas Pengelolaan Perbatasan: Tinjauan dari Perspektif Kebijakan Pengelolaan Perbatasan Indonesia" dalam Makalah Seminar "Pengelolaan Sumber Daya Alam dalam Perspektif Ketahanan Nasional”. Universitas Tanjungpura Pontianak, tanggal 8 Mei 2014. Tidak dipublikasikan.

Peraturan Pemerintah Republik Indonesia. No. 82 Tahun 2001 Tentang Pengelolaan Kualitas Air dan Pengendalian Pencemaran. Jakarta.

Poerwadarminta. (2006). Kamus Besar Bahasa Indonesia. Balai Pustaka. Jakarta.

Soewarno. (2000).”Hidrologi Operasional Jilid Kesatu". PT. Aditya Bakti, Bandung.

SNI 03-2819. (1992). Tata cara pengukuran debit sungai dan saluran terbuka dengan alat ukur arus tipe baling-baling. Jakarta.

Suhardjono. (1994). Kebutuhan Air Tanaman. Institut Teknologi Nasional. Malang.

Triatmodjo, Bambang, 1993b, Hidraulika II, Beta Offset, Yogyakarta 